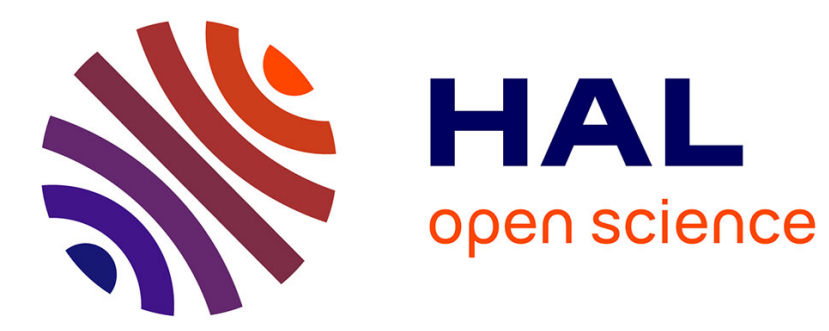

\title{
Mating behavior of Psammotettix alienus (Hemiptera: Cicadellidae)
}

\author{
Maja Derlink, Isabelle Abt, Romain Mabon, Charlotte Julian, Meta \\ Virant-Doberlet, Emmanuel Jacquot
}

\section{To cite this version:}

Maja Derlink, Isabelle Abt, Romain Mabon, Charlotte Julian, Meta Virant-Doberlet, et al.. Mating behavior of Psammotettix alienus (Hemiptera: Cicadellidae). Insect Science, 2018, 25 (1), pp.148-160. 10.1111/1744-7917.12379 . hal-02628561

\section{HAL Id: hal-02628561 \\ https://hal.inrae.fr/hal-02628561}

Submitted on 26 May 2020

HAL is a multi-disciplinary open access archive for the deposit and dissemination of scientific research documents, whether they are published or not. The documents may come from teaching and research institutions in France or abroad, or from public or private research centers.
L'archive ouverte pluridisciplinaire HAL, est destinée au dépôt et à la diffusion de documents scientifiques de niveau recherche, publiés ou non, émanant des établissements d'enseignement et de recherche français ou étrangers, des laboratoires publics ou privés.

\section{다)(1) $(5$}

Distributed under a Creative Commons Attribution - NonCommerciall 4.0 International 
1 Running title: Behaviour of the leafhopper P. alienus

2 Title for authors: M. Derlink et al.

3 Correspondence: Emmanuel Jacquot, INRA-Cirad-SupAgro Montpellier, UMR 385 BGPI, Cirad TA A-54K, 34398 Montpellier, France; Tel: +00(33) $4 \quad 99 \quad 62 \quad 48$ 36; email: emmanuel.jacquot@supagro.inra.fr

*: These two authors contribute equally to the work.

\title{
Original article
}

\section{Mating behaviour of Psammotettix alienus (Hemiptera: Cicadellidae)}

Maja Derlink $^{1 *}$, Isabelle $\mathrm{Abt}^{2,3, *}$, Romain Mabon ${ }^{2,3}$, Charlotte Julian ${ }^{2,3}$, Meta Virant-Doberlet ${ }^{1}$ and Emmanuel Jacquot ${ }^{2}$

${ }^{1}$ National Institute of Biology, Department of Organisms and Ecosystems Research, Večna pot 111, 1000 Ljubljana, Slovenia, ${ }^{2}$ INRA-Cirad-SupAgro Montpellier, UMR 385 BGPI, Cirad TA A-54K, 34398 Montpellier, France, and ${ }^{3}$ Bayer CropScience, 16 rue Jean Marie Leclair - CS 90106, 69266 Lyon Cedex 09, France

\begin{abstract}
The Wheat dwarf virus, the causal agent of the wheat dwarf disease, is transmitted by leafhoppers from the genus Psammotettix and currently the main protection strategy is based on the use of insecticide treatments. Sustainable management strategies for insect vectors should include methods that are targeted to disrupt reproductive behaviour and here we investigated the mating behaviour of Psammotettix alineus (Dahlbom 1850) in order to determine the role of vibrational signals in intra-specific communication and pair formation. Both genders spontaneously emit species- and sex-specific calling songs that consisted of
\end{abstract}

This is an Accepted Article that has been peer-reviewed and approved for publication in the Insect Science but has yet to undergo copy-editing and proof correction. Please cite this article as doi: 10.1111/1744-7917.12379.

This article is protected by copyright. All rights reserved. 
regularly repeated pulse trains and differ primarily in pulse train duration and pulse repetition time. Females preferred the conspecific male calling song. After a coordinated exchange of pulse trains, the male approached the stationary female. During the close range courtship and also immediately prior to copulatory attempts distinct male vibrational signals associated with wing flapping and wing vibrations were recorded from the substrate. In the presence of a receptive female, competing males emitted vibrational signals most likely aimed to interfere with male-female interaction. Mated females regained sexual receptivity after they laid eggs. Although results suggest that the viruliferous status of insects may have an effect on vibrational songs, our current results did not reveal a significant effect of virus on leafhopper performance in mating behaviour. However, the present study also suggests, that detailed understanding of plant-vector-virus interactions relevant for vector mating behaviour is essential for trying new approaches in developing future control practices against plant viruses transmitted by insect vectors.

Keywords: mating behavior, Psammotettix alienus, vibrational communication, Wheat dwarf virus

\section{Introduction}

Substrate-borne vibrations play an important role in mating behaviour of many insect pests from the order Hemiptera (e.g. Kanmiya, 2006; Čokl, 2008; Mazzoni et al., 2009; Mazzoni et al., 2010; Eben et al., 2015). Leafhoppers (Hemiptera: Auchenorrhyncha: Cicadellidae) are, with more than 22000 described species, one of the most speciose groups of phytophagus insects and are among the most important vectors of plant diseases (Weintraub \& Beanland, 2006). Vibrational signals have been described in a great number of leafhopper species (e.g., Tishechkin, 2000; Čokl \& Virant-Doberlet, 2003); however, taking into account the economic importance of leafhopper vectors and leafhopper diversity, it is surprising that a more detailed and comprehensive knowledge about the role of vibrational communication in leafhopper mating behaviour is limited to three species, namely Graminella nigrifrons (Heady \& Nault, 1991; Hunt \& Nault, 1991; Hunt \& Morton, 2001), Scaphoideus titanus 
56 (Mazzoni et al., 2009; Polajnar et al., 2014) and Aphrodes makarovi (de Groot et al., 2012;

57 Kuhelj et al., 2015).

In Cicadellidae, mate recognition and location are mediated exclusively by vibrational signals and the emerging general pattern of a leafhopper mating sequence is (a) that pair formation begins with the emission of a male advertisement call and (b) that after vibrational contact has been established, male searches for a replying stationary female (Heady \& Nault, 1991; Hunt \& Nault, 1991; Mazzoni et al., 2009; de Groot et al., 2012; Polajnar et al., 2014).

63

64

65

66

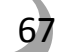

The leading role of the male in the pair formation is associated with the 'fly/jump/walk-call' strategy found in many Auchenorrhyncha (Hunt \& Nault, 1991; De Luca \& Cocroft, 2011; de Groot et al., 2012; Polajnar et al., 2014) and used by males to increase their signalling space in order to find the receptive females that are scattered unpredictably in the environment. The studies aimed at describing the role of vibrational signals in the context of species recognition showed (a) that vibrational signals are species- and sex-specific; (b) that signals emitted by males are more complex than those emitted by females; and (c) that partners exchange signals in a coordinated, stereotyped manner, in which a female reply follows vibrational signal emitted by a male. However, the results also revealed that leafhopper species differ greatly in the repertoire, structure and complexity of emitted signals, as well as in a duet structure (e.g. Tishechkin, 2000; Percy et al., 2008; Mazzoni et al., 2009; Derlink et al., 2014).

Cereals, important crops in the world for both human and domestic animals, can be infected by different pathogens of which the Wheat dwarf virus (WDV, genus Mastrevirus, family Geminiviridae [ICTV report, 2012]) is the causal agent of dwarfing, mottling and yellowing symptoms in wheat, barley and oat. The wheat dwarf disease, described for the first time in the 1960s in a wheat (Triticum aestivum L.) field in the former Czechoslovak 
Socialist Republic (Vacke, 1961), is among the most important sanitary issues in cereals production. WDV is transmitted from plant-to-plant by leafhoppers of the genus Psammotettix (Deltocephalinae), holartic insects commonly found in cereal fields and in grassland (Lindblad \& Areno, 2002). Parameters linked to the WDV/Psammotettix pathosystem are still poorly documented in the literature (reviewed in Abt \& Jacquot, 2015). Due to the lack of genetic resistance sources and the absence of anti-viral molecules, currently the main protection strategy used against WDV is based on the area-wide use of chemicals against the leafhoppers vectors.

The main objective of the present study was to provide the essential information on the reproductive behaviour of $P$. alienus (Dahlbom 1850), which is considered the main WDV vector (Zhang et al., 2010). Although vibrational signals emitted by males of $P$. striatus (L. 1758), P. confinis (Dahlbom 1850), P. narsikulovi (Dlabola 1960). P. pictipennis (Kirchbaum 1868) and P. poecilus (Flor 1861) have been recorded (Tishechkin, 1999; Tishechkin, 2000), the information on other aspects of vibrational communication associated with mating behaviour in this genus is lacking. Genus Psammotettix is considered a taxonomically challenging group and on the one hand, such knowledge is needed for a reliable delimitation and identification of vectors, since behavioural characters are the most accurate ones to delimit species (Schlick-Steiner et al., 2010). On the other hand, a more detailed knowledge on mating behaviour may also provide information on which the direction of more environmentally friendly control practices can be developed (Weintraub \& Beanland, 2006).

Due to increased awareness of harmful effects of pesticides on biodiversity and human health, the exploitation of vibrational signals in pest management has in recent years received an increased attention (Čokl \& Millar, 2009; Eriksson et al., 2012; Mankin et al., 2013; 
Polajnar et al., 2015; Polajnar et al., 2016; Korinšek et al., 2016). In the study we also

103

104

105

106

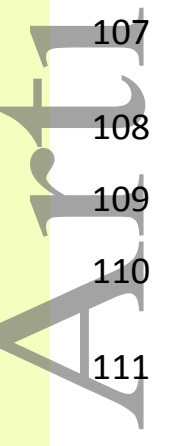

112

113

114

115

116

117

118

119

120

121

122

123

124

included virus-free and viruliferous individuals in order to obtain some preliminary

information whether viruliferous status of insects has an effect on the pre-copulatory mating performance.

\section{Materials and Methods}

\section{Insects}

Adult $P$. alienus leafhoppers were collected using a sweep net in June and September in years 2012 and 2013 in various cereal fields in North and South France and also from grassland and vineyards in West Slovenia in August 2014.

Based on the sanitary status of the gravid females collected in 2012 (determined by PCR methods [see Supplementary Material]), virus-free and viruliferous (WDV wheat strain [WDV-w] and WDV barley stain [WDV-b]) leafhopper populations were initiated using selected progenies. These leafhopper populations were reared in large plexi-glass cages $(50 \times$ $50 \times 80 \mathrm{~cm})$ in a temperature controlled chamber $\left(24^{\circ} \mathrm{C}\right.$ during the day $/ 20^{\circ} \mathrm{C}$ during the night, $40 \% \mathrm{RH}, 16 / 8$, day/night period). Fresh potted plants were added to the cages every month. While virus-free and WDV-w leafhoppers were maintained on wheat cv. Sunstar (Posadas \& Henry, 2002), WDV-b Psammotettix populations were maintained on barley cv. Express (Sadeghi et al., 2000) according to the host specificity of the WDV strains described in the literature (reviewed in Abt \& Jacquot, 2015).

Leafhoppers collected in the field in 2013 were maintained in the laboratory individually on a 2-leaf cereal plantlet covered by a micro-perforated cellophane bag in a temperature 
controlled chamber as described above. For four weeks following the collection, the individual rearing systems were daily monitored for the presence of eggs and larvae. For each of the 330 gravid females collected in field, up to 10 larvae were transferred individually on 128 young cereal plantlets and reared as described above in order to obtain virgin adults. The

129

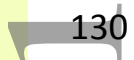

131

132

133

134

135

136

137

138

139

140

141

142

143

sanitary status of the 330 gravid females was determined by PCR method (see Supplementary Material).

Individuals collected in Slovenia in 2014 were maintained in individual rearing systems as described above until used in the experiments. The sanitary status of the insects was determined by PCR method.

\section{Recording vibrational signals and behaviour}

Experimental set-up All experiments were performed on wheat $c v$. Sunstar plantlets (approximate height $14 \mathrm{~cm}, 2$-leaf stage, 1 leaf removed) at room temperature $\left(20-25^{\circ} \mathrm{C}\right.$ and at $40 \%-50 \% \mathrm{RH})$. Individual plantlet was planted in a plastic vial filled with vermiculite and placed upright into a jar filled with moist artificial substrate. The plantlet was positioned within a circular opening ( $10 \mathrm{~cm}$ diameter) of a custom made wooden tripod and the hole was covered with overlapping incised paper circles surrounding the plant thus creating a platform and separating the upper and lower part of the plantlet (de Groot et al., 2012). The upper part was covered with a transparent plastic vial (height $9.5 \mathrm{~cm}$, diameter $2.5 \mathrm{~cm}$ ) to prevent leafhoppers from escaping.

Vibrational signals were registered from the plantlet $1 \mathrm{~cm}$ below the platform, with a laser vibrometer (PDV-100, Polytec, GmbH, Waldronn, Germany) and stored in a computer using a Sound Blaster 2 ZS sound card (Creative, Singapore) and Cool Edit pro 2.0 software 
(Syntrillium Software, Phoenix, USA) at the sampling rate $48 \mathrm{kHz}$ and 16 bit resolution. In order to increase reflectance, a small piece of reflective tape was placed on the stem at the 150 recording location $1 \mathrm{~cm}$ below the platform.

The set-up also enabled playback stimulation with the pre-recorded vibrational signals 152 (see below). We applied vibrational stimuli to the plantlet stem approximately $3 \mathrm{~cm}$ below the platform via the conical tip of the 5-cm metal rod (4 $\mathrm{mm}$ in diameter) screwed firmly into the head of a vibration exciter (Minishaker type 4810, Brüel \& Kjær, Nærum, Denmark). The vibration exciter was driven from the computer via the above mentioned sound card by Cool Edit Pro2 program. The amplitude of stimulation was adjusted to the level of naturally emitted vibrational signals registered at the point of recording.

\section{Male and female calling songs}

Calling signals were defined as signals that are emitted spontaneously by isolated individuals (de Groot et al., 2012). We conducted seven overnight recording sessions (between 18:00 and 08:00 hours) of single individuals that included five males (three virusfree, one WDV-w viruliferous, one WDV-b viruliferous) and two females (both virus-free). A single leafhopper was placed to the plantlet above the platform and recorded vibrational signals were automatically stored in a computer every 30 min using Raven 1.4 software (Cornel Laboratory of Ornithology, Ithaca, USA). From the recordings, we determined the time periods when leafhoppers were signalling and measured the duration of calling bouts.

Subsequent experiments were carried out between 08:00 and 17:00 hours. Vibrational activity of single leafhoppers was recorded for 15 to $60 \mathrm{~min}$. In order to induce signalling, females were stimulated with a pre-recorded P. alienus male call. From our library of 
recordings, we randomly chose a calling song of one virus-free male and the stimulatory

172

\section{7}

188

189

190

191

192

193 sequence was $7.6 \mathrm{~s}$ long and included 6 pulse trains (pulse train duration, mean $\pm \mathrm{SD}=0.11 \pm$ $0.01 \mathrm{~s}$; pulse train repetition time $=1.51 \pm 0.29 \mathrm{~s}$ ). If a female did not start emitting vibrational signals, stimulation was repeated every $10 \mathrm{~s}$ for $20 \mathrm{~min}$.

In the analyses of male calls, we included signals from 28 healthy males and from 7 and 12 WDV-w and WDV-b viruliferous leafhoppers, respectively. In the analyses of female calls we included signals from 18 virus-free leafhoppers and from 5 and 14 WDV-w and WDV-b viruliferous individuals, respectively. We measured the following parameters: pulse train duration, pulse repetition time within the train, pulse train repetition time, calling bout duration and dominant frequency.

Females used in mating experiments (see below) were after copulation kept separately on young wheat plantlets and after they had laid eggs their progenies were maintained as separate lineages. Vibrational signals of 12 F1 individuals ( 9 males and 3 females) from three virus-free lineages were recorded two months after the copulation as described above.

\section{Female preferences}

To test the preference of $P$. alienus females, 26 females ( 9 virus-free, 17 viruliferus [WDVb]) were placed singly on a plantlet and stimulated with a sequence that included calling songs of virus free and viruliferus (WDV-b) P. alienus, calling songs of two $P$. confinis males and male advertisement call of the leafhopper Gramphocraerus ventralis (Table 1). Within the stimulation sequence, each song was repeated five times in a random order separated by $30 \mathrm{~s}$ silent intervals. All male songs included in the stimulatory sequence were taken from our 
library of recordings and had been recorded with the laser vibrometer mentioned above not

more than $3 \mathrm{~cm}$ away from the calling male. Vibrational signals of Psammotettix males were registered on a wheat plantlet, while the male call of $G$. ventralis was recorded on the clover

197

198

199

200

201

202

203

204

205

206

207

208

209

210

211

212

213

214

215

216

(Trifolium pratense). Each female was tested with the same stimulation sequence; however, for each trial the starting song was set randomly. Since female calling song can last for several minutes, the male calling song during which the female started signalling was scored as the preferred call. The playback was stopped at the end of the male song; however, the recordings continued until the end of the female calling bout. We measured the signalling latency (time from the beginning of the preferred calling song to the first emitted female pulse train) and the duration of the emitted female calling song.

\section{Mating behaviour}

Eighteen pairs of virgin individuals were used to describe mating behaviour and we included virus-free leafhoppers, as well as viruliferous individuals (Table 2). A male and a female were placed on a plantlet and their behaviour and emitted vibrational signals were monitored until the end of copulation. Care was taken to position the partners as far apart as possible; however, due to their small size (3-4 mm) and high mobility, the initial distance between the male and the female on the plantlet was variable. Vibrational signals emitted during the mating sequence were recorded as described above. For seven pairs leafhopper behaviour together with the emitted vibrational signals was simultaneously recorded with a 3CCD video camcorder (Canon DM XM2) fitted with a 4.2-84 mm zoom lens (Table 2).

In all experiments, we monitored the following parameters: male calling latency (time from the beginning of the experiment to the first pulse train emitted by male), female calling 
217 latency (time from the beginning of the male calling song to the first pulse train emitted by

218 the female), the number of emitted courtship signals, mating sequence duration (time from

219 the emission of the first male or female pulse train to the beginning of copulation) and 220 duration of copulation (Table S1). Whenever possible, we also determined the search

221 duration (time from the onset of a duet to the location of the female) and close-range courtship duration (time between the location of the female and the beginning of copulation).

In addition, 49 females of $P$. alienus collected in the field in September 2013 that had laid eggs in the laboratory (i.e. they mated in the field) were after one month after egg deposition stimulated with a pre-recorded P. alienus song described above in order to determine whether they regained sexual receptivity.

\section{Rivalry}

To stage a rivalry situation, two males $(N=25$ male pairs; 12 pairs of virus-free males, 5 pairs of a virus-free male and a WDV-b male, 3 pairs of a WDV-w male and WDVb male, 5 pairs of WDV-b males) were placed on a wheat plantlet and we played them a pre232 recorded female calling song. From our library of recordings, we randomly chose a $60 \mathrm{~s}$ long 233 recording of a calling song of one virus-free female. The sequence contained 46 pulse trains 234 (duration: mean $\pm \mathrm{SD}=0.56 \pm 0.04 \mathrm{~s}$; pulse train repetition time: $1.31 \pm 0.07 \mathrm{~s}$ ). The 235 stimulatory sequence was played in a loop throughout the experiment; however, we randomly stopped the playback for $30 \mathrm{~s}$ intervals. Vibrational activity was recorded for $30 \mathrm{~min}$. 
Pulse was defined as a unitary homogenous parcel of sound of finite duration (de Groot et al., 2012), while a pulse train was characterized as a group of pulses with a characteristic

241 sequence or form. We defined song as a bout of repeated pulse trains. Since pulse train 242 repetition time was not always regular, the end of the bout was determined at the start of the 243 inter-pulse train interval longer than $5 \mathrm{~s}$. Vibrational signals recorded exclusively during the later close-range stages of the mating sequence were defined as courtship signals, while signals emitted immediately prior to copulation attempts were termed pre-copulatory signals.

Data are presented as means and standard deviations, together with the numbers of 247 leafhoppers from which signals were obtained $(N)$ and the numbers of signals analysed $(n)$.

Dominant frequency data are presented as medians together with ranges. For quantifying calling activity of single leafhoppers throughout the night, the cumulative calling time was used to represent the calling activity in each hour. We obtained the cumulative calling time for each individual by summing up the durations of all calling bouts (i.e. calling songs) in these periods.

The parameters of calling songs (pulse repetition time, pulse train duration, pulse train 254 repetition time and dominant frequency) in each sex were compared between all viruliferous

255

256

257 leafhoppers (WDV-w and WDV-b) and virus-free individuals (collected in the field and the progeny). Similarly, in each sex these parameters have been compared between virus-free individuals from the field and virus-free progeny reared in the laboratory. Data were first checked for normality with Shapiro-Wilk normality test and accordingly analysed either with nonparametric Wilcoxon rank sum test or parametric Student`s $t$-Test. The proportions of all females responding to either conspecific or heterospecific male calls included in the stimulatory sequence used in female preference tests were compared with Test of equal of 
given proportions, while correlations between sanitary status of the females and their

263 preferences for male calling songs were calculated using two-tailed Fisher's exact test. All

264 statistical analyses were conducted using $\mathrm{R}$ version 3.2.1.

265

266

267

268

269

270

271

272

273

274

275

276

277

278

279

280

281

282

283

\section{Results}

\section{General observations}

Overnight recordings of single individuals revealed that both sexes emit vibrational signals spontaneously. The overall calling time during the night was longer in female (13020 $\mathrm{s}$ and $8522 \mathrm{~s})$ than in males $(2413 \pm 2041 \mathrm{~s})$, and was a result of longer pulse train durations (see below). Although calling activity varied between individuals, the emerging pattern suggests that while female calling activity is low in the period between midnight and 6 am, males are calling throughout the whole night (Fig. 1).

All recorded vibrational signals associated with the earlier stages of the mating sequence consisted of a series of single pulses and the main difference between the male calling song, female calling song and male rivalry song was in the pulse train duration and pulse repetition time (Table 3, Figs. 2, 5).

\section{Male calling song}

Male calling song is characterized by short pulse train duration, highly regular pulse repetition time within the train and less regular pulse train repetition time within the song (Fig. 2, Table 3). Pulse trains span broad frequency range and have clear harmonic structure 
with dominant frequency between 130 and $1000 \mathrm{~Hz}$. Duration of the registered male calling songs was variable $(10.5 \pm 5.9 \mathrm{~s}, N=70, n=70)$.

The analysed dominant frequencies, pulse train durations and pulse repetition time of the male calling song did not differ significantly between the virus-free and viruliferous males (Student's $t$-Test, $P>0.05$ ), while viruliferous males emitted songs with significantly longer pulse train repetition time (Student's $t$-Test, $P=0.04$ ).

Parameters of calling song emitted by field collected virus-free males and by virusfree males from a progeny produced in the laboratory were similar; however, in the latter, the pulse train repetition time was significantly longer (Student's t-Test, $P=0.008$ ) (Table 3). However, eight of the nine F1 males tested belonged to the same lineage that appears to be characterized by long pulse train repetition time (Table S2).

\section{Female calling song}

In comparison with the male calling song, female calling song is characterized by longer pulse train duration, longer and less regular pulse repetition time within the train and more regular pulse train repetition time (Figs. 2, 3, Table 3). As in the male calling song, pulse trains span broad frequency range and also have similar dominant frequencies; however, without the harmonic structure. Duration of the registered female calling songs was highly variable $(42.92 \pm 43.95 \mathrm{~s} ; N=41, n=41)$. The analysed parameters of female calling song did not differ significantly between the virus-free and viruliferous females (Student's $t$ Test, $P>0.05$ ) and neither did between the female progeny and virus-free females (Student's $t$-Test, $P>0.05)$. 
In the tested $P$. alienus females the emission of calling song was clearly associated wit h the conspecific male calling song (Test of equal or given proportions, $P<0.001$ ) (Table 4 ). None of the females responded to $G$. ventralis male advertisement call; however, four $P$. alie nus females started signalling during the playback of the $P$. confinis male calling song. In thre e of these females the preceding male calling song in the stimulatory sequence was the consp ecific male song. Preferences for $P$. alienus males and $P$. confinis males in the virus-free and viruliferous females did not differ significantly (Fisher's exact test, $P=0.591$ ) and we did not observe any correlation in preferences for the male calling songs emitted by the virus-free an d viruliferous $P$. alienus males and virus-free and viruliferous females (Fisher's exact test, $P$ $=1$ ), however the number of the tested individuals was low (Table 4).

\section{Mating behaviour}

In general, observations did not reveal significant differences in mating behaviour between the virus-free and virulifeorus leafhoppers (Table S1). On avarage, the complete mating sequence duration (excluding copulation) was $54 \pm 26 \min$ (minimum $=11 \mathrm{~min}$, maximum $=101 \min , N=15)$. The main stages of the mating sequence in $P$. alienus are shown in the Supplementary movie and in Fig. S1. Broadly, the stages can be described as recognition, approach, courtship and pre-copula phase. In 17 out of 18 trials that finished with copulation, the first registered vibrational signal was a male calling song (male calling latency $=199 \pm 255 \mathrm{~s}$ ). On average, females emitted calling song $88 \pm 164 \mathrm{~s}$ after the first emitted pulse train by male. The first vibrational interaction was a coordinated duet in which a male and a female regularly exchanged pulse trains in an M-F-M-F sequence (Fig. 3). 
After vibrational contact was established, the male started to approach the stationary

331 female. On average, the approach stage lasted $24 \pm 18$ min $($ minimum $=3$ min, maximum $=$

$33251 \mathrm{~min}, N=7$ ). During this stage vibrational interaction between a male and a female was

333 less precisely coordinated and leafhoppers continued to emit calling songs when the partner

334 stopped calling (Fig. 2b). Males were signalling only when they were not walking and often they only sporadically emitted single pulse trains.

When the male reached the female, he positioned himself behind or on the side of the

female, facing in the same direction (Fig. S1A, B). On average, the close-range courtship lasted for $34 \pm 17$ minutes $($ minimum $=10 \mathrm{~min}$, maximum $=64 \mathrm{~min}, N=7$ ). While during the courtship stage most females stopped calling, most males continued emitting the calling song; however, male calling activity was lower than during the earlier stages. Courtship stage was 341 usually associated with a continuous emission of pulses emitted with irregular repetition time; however, we were not able to determine whether they were produced by a male or a female.

343 During the close-range courtship males were rubbing and tapping the females with the front 344 leg (Fig. S1C) and flapping their wings (Fig. S1D). The latter resulted in distinct courtship 345 vibrational signals recorded in the substrate (Table 3, Fig. 4). Pulse trains produced by wing 346 flapping span broad frequency range and within the main frequency band $(100-1000 \mathrm{~Hz})$

347 they have a clear harmonic structure with dominant frequency between 100 and $400 \mathrm{~Hz}$. 348 Courtship signals produced by wing flapping were registered in all mating sequences that 349 concluded with copulation $($ minimum $=2 ;$ maximum $=25, N=16$ ).

Copulation attempts were associated with a distinct complex vibrational signal composed 351 of a 1-3 s long pulse train (buzz), followed by high amplitude pulses produced by wing 
flapping and vibrating one wing over the female (Fig. 4 and Fig. S1E). The average duration 353 of copulation was $522 \pm 88 \mathrm{~s}(N=11)$.

354 Results of recordings of virus-free females that had mated in the field and have laid eggs 355 in the laboratory showed that $26 \%$ of $P$. alienus females started signalling again when 356 stimulated with the conspecific male calling song.

357

358

359

\section{Rivalry behaviour}

In seven out of 25 tested male pairs that were presented with a playback of the female calling song, males emitted another type of vibrational signal (Fig. 5). These signals were recorded in two pairs of virus-free males, two pairs of a virus-free male and a WDV-b male and three pairs that included a WDV-b male and a WDV-w male. Although males usually started to emit this signal in the interval between pulse trains in the female calling song, it always overlapped at least part of the pulse train emitted by the female (Fig. 5). Although the temporal and spectral parameters of this putative masking signal were variable, it is characterized by a long pulse train duration and long pulse repetition time (Table 3). Pulse train repetition time is not regular. Masking signal spans broad frequency range with dominant frequencies between 400 and $1200 \mathrm{~Hz}$ (Fig. 5).

In all trials in which the putative masking signals were recorded, they were preceded by the male calling song emitted by a live male. On average we recorded 23 ( $\mathrm{SD}=19$, minimum $=2$, maximum $=51)$ masking signals per trial. Due to the small size of $P$. alienus leafhoppers, it was not possible to determine which male emitted the recorded calling songs and masking signals. 
Discussion

377 Results of the present study show that as in other Cicadellidae, mating behaviour in $P$. 378 alienus is stereotyped and associated with the emission of species- and sex-specific

379 vibrational signals. However, our results also revealed important differences with other leafhopper species so far studied in detail. The unique features of vibrational communication in P. alienus are: (i) that the pair formation is initiated by either gender; (ii) the same general,

simple structure of male and female calling song and (iii) progression from a patterned to a loosely coordinated duet.

For leafhoppers, it is generally accepted that mating sequence is initiated by the emission of male calling signals (Claridge, 1985; Hunt \& Nault, 1991; Čokl \& Virant-Doberlet, 2003; Mazzoni et al., 2009; de Groot et al., 2012). However, one older study indicated that females also show low levels of spontaneous calling activity and can rarely also initiate a pair formation (Saxena \& Kumar, 1984). Although in mating experiments, most duets were initiated by the male, taken together, the structure of the female calling song (see below) and high spontaneous female calling activity in overnight recordings suggest that in $P$. alienus females may be equally likely to trigger the exchange of vibrational signals. While apparently rare in leafhoppers, such behaviour seems to be more common in planthoppers (e.g. VirantDoberlet \& Žežlina, 2007; Mazzoni et al., 2010). However, mating systems are shaped in part also by ecological aspects of the environment, including population density (Virant-Doberlet \& Žežlina, 2007).Despite considerable economic importance of leafhoppers, we still know very little about their mating systems and reproductive strategies under field conditions and 
future studies should provide more insight into mechanisms that are involved in the evolution of different communication strategies in Auchenorrhyncha.

In contrast to males, mated leafhopper females stop signalling and, consequently, males, cannot locate them (Bailey \& Nuhardiyati, 2005; Mazzoni et al., 2009) and it is usually accepted that in leafhoppers, females, unlike males, most likely mate only once in their lifetime. Our results show that after they laid eggs mated $P$. alienus females regained their sexual receptivity. In the absence of studies of $P$. alienus mating behaviour under field conditions it is not clear whether this result reflects a natural situation. However, it has been observed that in the field leafhopper females can mate multiply (Hayashi \& Kamimura, 2002) and that when ejaculate size is small, some females become responsive again after a postmating refractory period (Bailey \& Nuhardiyati, 2005).

Calling signals are long-range signals associated with the initial stage of mating behaviour when individuals advertise their presence and readiness to mate and should reveal the identity (species and gender) of the signaller and also provide information necessary to determine its location (Čokl \& Virant-Doberlet, 2003). This is in agreement with our results that in $P$. alienus vibrational signals used in the recognition stage enabled a reliable identification of the partner. However, studies done so far show that in leafhoppers calling signals emitted by males are more complex than those emitted by females (Čokl \& VirantDoberlet, 2003; Percy et al., 2008; Mazzoni et al., 2009; de Groot et al., 2012; Derlink et al., 2014). In contrast, in $P$. alienus male and female calling songs do not differ in their complexity and in both genders calling songs are simple and formed by regularly emitted pulse trains. In particular, female calling song in this respect more closely resembles female vibrational signals in the hemipteran species in which females initiate vibrational exchange 
between partners (e.g. the planthopper Hyalesthes obsoletus (Mazzoni et al., 2010) and the

421 pentatomid bugs [Čok1, 2008]) than female replies described in other leafhopper species.

422 Consequently, a duet structure in P. alienus also differs from the exchange of male and 423 female vibrational signals described in other Cicadellidae (e. g. Heady et al., 1986; Percy et 424 al., 2008; Mazzoni et al., 2009; Derlink et al., 2014).

Coordinated duet observed in the recognition stage to some extent resembles a duet structure described in the early stages of the mating sequence in the leafhopper S. titanus (Polajnar et al., 2014) and the planthopper H. obsoletus (Mazzoni et al., 2010). Additional studies are needed to determine whether in $P$. alienus such coordinated duet results from resetting the endogenous oscillator generating the song rhythm by the perceived pulse trains emitted by the partner or partners listen out for each other and reply (Polajnar et al., 2014).

431 During the approach stage, a continuous emission of female calling song may be important 432 for successful and quick localization. For small plant-dwelling insects relying on vibrational 433 communication, locating the partner is difficult (Virant-Doberlet et al., 2006). The 434 experimental environment used in the current study was not complex enough to test the 435 localization ability of $P$. alienus; however, even for leafhoppers with the body size of around $436 \quad 3-4 \mathrm{~mm}$, vibrational signals provide a reliable information needed to locate the female 437 (Polajnar et al., 2014). As in other leafhoppers (Mazzoni et al., 2009; Kuhelj et al., 2015), P. 438 alienus males were alternating periods of signalling with periods of walking. Less 439 coordinated duet observed during the approach stage may result from inability to coordinate 440 the activity of muscles involved in signal production and walking, or from inability to detect 441 female vibrational signals while walking, since leg movements likely stimulate the same leg 442 mechanoreceptors that also detect vibrational signals. 
As in some other Auchenorrhyncha that emit relatively simple vibrational signals during

444 the earlier stages of the mating sequence (e.g. Virant-Doberlet \& Žežlina, 2007; Mazzoni et al., 2009), in P. alienus more complexity has been introduced at the later stages of mating behaviour. In leafhoppers, production of vibrational signals is costly (Kuhelj et al., 2015) and

447 it has been hypothesized that the cost may be rationalized by emitting more complex and energetically more demanding signals after the recognition and location of the female have been completed (Polajnar et al., 2014). Wing flapping and wing vibrations produced by males during the close-range stages have been observed in several leafhopper species (Shaw et al., 1974; Shaw, 1976; Saxena \& Kumar, 1984; Heady et al., 1986; Hunt \& Nault, 1991). Our results show that wing movements result in distinct and stereotyped vibrational signals; however, the role of these signals is not clear since wing flapping can also be associated with visual and/or chemical signals.

Our results suggest that in the presence of a receptive female, competing $P$. alienus males emit vibrational signals most likely to interfere with male-female communication. Such signals have been described in other leafhopper species (Mazzoni et al., 2009; Kuhelj et al., 2015). The data obtained in the current study by playback experiments are not sufficient to determine whether these putative masking signals are used to disrupt a coordinated malefemale duet or to mask female calling song. Future studies should reveal whether this species coordinated duet is vulnerable to disruption and whether rival males also use satellite behaviour to approach the female duetting with another male.

Preliminary results obtained in the current study suggest that the viruliferous status of the leafhopper does not have a significant effect on leafhopper performance in mating behaviour; however, our results also showed that pulse train repetition time in male calling song was 
significantly longer in viruliferous than in the virus-free males. Although due to the low

467 numbers of tested individuals the current results are not conclusive, they show that it is worthwhile testing in more detail whether reproductive behaviour in P. alienus is influenced by the virus. Plant viruses can modify vector performance via indirect effects of virus infection on plant nutritional composition (Fiebig et al., 2004) or directly via altering vector behaviour and physiology (Ingwell et al., 2012; Moreno-Delafuente et al., 2013; Wan et al., 2015). Behaviour associated with mating (advertising, walking, rivalry interactions) is energetically demanding (Kuhelj et al., 2015) and better availability of nutrients in infected plants may have an important role on performance (Morehouse et al., 2010). Leafhoppers keep their feeding stylets inserted into plant tissue while emitting vibrational signals (Kuhelj et al., 2015) and there is indirect evidence that $P$. alienus males may also be signalling while feeding (Tholt et al., 2015). Furthermore, virus infection also alters other parameters of the host plant (phenotypic and physiological) (Scholthof et al., 2011) that can affect plant transmission properties that can in turn affect the ability of leafhoppers to communicate with conspecifics. Future studies on virus-host plant-vector interactions should also take these potential effects into account.

Developing new approaches in pest management that could help to reduce the use of 483 pesticides is one of the main challenges in sustainable agriculture. Until recently, exploitation of vibrational signals used in intraspecific communication has been rarely considered in pest management even from a theoretical viewpoint. However, recent work done on S. titanus (Eriksson et al., 2012; Polajnar et al., 2016) and psyllid Diaphorina citri (Mankin et al., 487 2013) highlights that, although currently due to the lack of obvious technical solutions, the 
488

489

490

491

492

493

494

495

496

497

498

499

500

501

502

503

504

505

506

507

508

509

510

511

implementation of acoustic methods in pest management may seem limited, more directed efforts may provide new perspectives in management strategies.

\section{Acknowledgments}

The authors acknowledge Gabrijel Seljak for his help in leafhopper identifications during field survey in Western Slovenia. The presented work has been supported by the Institut National de la Recherche Agronomique (France), Montpellier SupAgro (France) and by funding from the Slovenian Research Agency (research programme P1-0255).

\section{References}

Abt, I. and Jacquot, E. (2015) Wheat dwarf. Virus Diseases of Tropical and Subtropical Crops (eds P. Tennant \& R. Fermin), CAB International, Plant protection series, 2015, $27-41$

Bailey, W.J. and Nuhardiyati, M. (2005) Copulation, dynamics of sperm transfer and female refractoriness in the leafhopper Balclutha incisa (Hemiptera: Cicadellidae: Deltocephalinae). Physiological Entomology, 30, 343-352

Cocroft, R.B., Shugart, H.J., Konrad, K.T. and Tibbs K. (2006) Variation in plant substrates and its consequences for insect vibrational communication. Ethology, 112, 779-789

Čokl, A. (2008) Stink bug interaction with host plants during communication. Journal of Insect Physiology, 54, 1113-1124

Čokl, A. and Millar, J.G. (2009) Manipulation of insect signalling for monitoring and control of pest insects. Biorational Control of Arthropod Pests: Application and Resistance Management (eds I. Ishaaya \& R. Horowitz), Springer, Dordrecht, pp. 279-316

This article is protected by copyright. All rights reserved. 
512 Čokl, A. and Virant-Doberlet, M. (2003) Communication with substrate-borne signals in $513 \quad$ small plant-dwelling insects. Annual Review of Entomology, 48, 20-50

514 de Groot, M., Derlink, M., Pavlovčič, P., Prešern, J., Čokl, A. and Virant-Doberlet, M. (2012) 515 Duetting behaviour in the leafhopper Aphrodes makarovi (Hemiptera: Cicadellidae). Journal of Insect Behaviour, 25, 419-440

De Luca, P.A. and Cocroft, R.B. (2011) The influence of age on male mate-searching behaviour in thornbug treehoppers. Ethology, 117, 1-11

Derlink, M., Pavlovčič, P., Stewart, A.J.A. and Virant-Doberlet, M. (2014) Mate recognition in duetting species: the role of male and female vibrational signals. Animal Behaviour, 90, 181-193

Eben, A., Mühlethaler, R., Gross, J. and Hoch, H. (2015) First evidence of acoustic communication in the pear psyllid Cacopsylla pyri L. (Hemiptea: Psyllidae). Journal of Pest Science, 88, 87-95

Eriksson, A., Anfora, G., Lucchi, A., Lanzo, F., Virant-Doberlet, M. and Mazzoni, V. (2012) Exploitation of insect vibrational signals reveals a new method of pest management. PLoS ONE, 7, e32954. doi: 10.1371/journal.pone.0032954

528 Hayashi, F. and Kamimura, Y. (2002) The potential for incorporation of male derived 529 proteins into developing eggs in the leafhopper Bothrogonia ferruginea. Journal of Insect Physiology, 48, 153-159

531 Heady, S.E. and Nault, L.R. (1991) Acoustic signals of Graminella nigrifrons (Homoptera: Cicadellidae). Great Lakes Entomology, 24, 9-16 
Heady, S.E., Nault, L.R., Shambaugh, G.F. and Fairchild, L. (1986) Acoustic and mating behavior of Dalbulus leafhoppers (Homoptera: Cicadellidae). Annals of Entomological Society of America, 79, 727-736

536 Hunt, R.E. and Morton, T.L. (2001) Regulation of chorusing in the vibrational communication system of the leafhopper Graminella nigrifrons. American Zoology, 41, $1222-1228$

Hunt, R.E. and Nault, L.R. (1991) Roles of interplant movement, acoustic communication and phototaxis in mate location behavior of the leafhopper Graminella nigrifrons. Behavioral Ecology \& Sociobiology, 28, 315-320

King, A.M.Q., Adams, M.J., Carstens, E.B. and Lefkowitz, E.J (2012) ICTV Report: "Virus taxonomy: classification and nomenclature of viruses: Ninth Report of the International Committee on Taxonomy of Viruses". Elsevier Academic Press, San Diego, USA.

Ingwell, L.L., Eigenbrode, S.D. and Bosque-Pérey, N.A. (2012) Plant viruses alter insect behaviour to enhance their spread. Scientific Reports, 2, 578. doi: 10.1038/srep00578

Kanmiya, K. (2006) Mating behaviour and vibratory signals of whiteflies (Hemiptera: Aleyrodidae). Insect Sounds and Communication: Physiology Behaviour and Ecology (eds. S. Drosopoulos \& M.F. Claridge), Taylor and Francis, Boca Ratoon, pp. 365-376

550 Korinšek, G., Derlink, M., Virant-Doberlet, M. and Tuma, T. (2016) An autonomous system of detecting and attracting leafhopper males using species- and sex-specific substrate borne signals. Computers \& Electronics in Agriculture, 123, 29-39.

Kuhelj, A., de Groot, M., Pajk, F., Simčič, T. and Virant-Doberlet, M. (2015) Energetic cost 554 of signalling in a leafhopper. Behavioral Ecology \& Sociobiology, 69, 815-828 
Lindblad, M. and Areno, P. (2002) Temporal and spatial population dynamics of Psammotettix alienus, a vector of wheat dwarf virus. International Journal of Pest Management, 48, 233-238

558

559

560

561

562

Mankin, R.W., Rohde, B.B., McNeill, S.A., Paris, T.M., Zagvazdina, N.I. and Greenfeder, S. (2013) Diaphorina citri (Hemiptera: Liviidae) responses to microcontroller-buzzer communication signals of potential use in vibration traps. Florida Entomology, 96, $1546-1555$.

Mazzoni, V., Prešern, J., Lucchi, A. and Virant-Doberlet, M. (2009) Reproductive strategy of the Nearctic leafhopper Scaphoideus titanus Ball (Hemiptera: Cicadellidae). Bulletin of Entomological Research, 99, 401-413

Mazzoni, V., Lucchi, A., Ioriatti, C., Virant-Doberlet, M. and Anfora, G. (2010) Mating behaviour of Hyalesthes obsoletus (Hemiptera: Cixiidae). Annals of Entomological Society of America, 103, 813-822

Moreno-Delafuente, A., Garzo, E., Moreno, A. and Fereres, A. (2013) A plant virus manipulates the behaviour of its whitefly vector to enhance its transmission efficiency and spread. PLoS ONE, 8, e61543.

Percy, D.M., Boyd, E.A. and Hoddle, M.S. (2008) Observations of acoustic signals in three sharpshooters: Homalodisca vitripennis, Homalodisca liturata and Graphocephala atropunctata (Hemiptera: Cicadellidae). Annals of Entomological Society of America, $101,253-259$

Polajnar, J., Eriksson, A., Lucchi, A., Anfora, G., Virant-Doberlet, M. and Mazzoni, V. (2015) Manipulating behaviour with substrate-borne vibrations - potential for insect pest control. Pest Management Science, 71, 15-23

This article is protected by copyright. All rights reserved. 
600

Polajnar, J., Eriksson, A., Virant-Doberlet, M. and Mazzoni, V. (2016) Mating disruption of a grapevine pest using mechanical vibrations: from laboratory to the field. Journal of Pest Science, in press (doi:10.1007/s10340-015-0726-3)

Polajnar, J., Eriksson, A., Rossi, S.M.V., Lucchi, A., Anfora, G., Virant-Doberlet, M. and Mazzoni, V. (2014) The process of pair formation mediated by substrate-borne vibrations in a small insect. Behavioural Processes, 107, 68-78

Posadas, G. and Henry, M. (2002). Resistance to BYDV-PAV and CYDV-RPV in a bread wheat x agrotricum cross. Barley Yellow Dwarf Disease: Recent Advances and Future Strategies (eds. M. Henry \& A. McNab), CIMMYT, Mexico. 127pp.

Sadeghi, S.E., Dedryver, C.A., Riault, G. and Tanguy, S. (2000) Variation in virus content among individual leaves and roots of barley and wheat infected with a BYDV-PAV isolate. Journal of Agricultural Science and Technology, 2, 151-160

Saxena, K.N. and Kumar, H. (1984) Acoustic communication in the sexual behavior of the leafhopper Amrasca devastans. Physiological Entomology, 9, 77-86

Schlick-Steiner, B.C., Steiner, F.M., Seifert, B., Stauffer, C., Christian, E. and Crozier, R.H. (2010) Integrative taxonomy: a multisource approach to exploring biodiversity. Annual Review of Entomology, 55, 421-438.

Scholthof, K.B.G., Adkins, S., Czosnek, H., Palukaitis, P., Jacquot, E., Hohn, T., Saunders, K., Candresse, T., Ahlquist, P., Hemenway, C. and Foster, G.D. (2011) Top 10 Plant Viruses in Molecular Plant Pathology. Molecular Plant Pathology, 12, 938-954

Shaw, K.C. (1976) Sounds and associated behavior of Agallia constricta and Agalliopsis novella (Homoptera: Auchenorrhyncha: Cicadellidae). Journal of Kansas Entomological Society, 49, 1-17 
601

602

603

604

605

606

607

608

Shaw, K.C., Vargo, A. and Carlson, O.V. (1974) Sounds and associated behavior of some species of Empoasca. Journal of Kansas Entomological Society, 47, 284-307

Tholt, G., Samu, F. and Kiss, B. (2015) Feeding behaviour of a virus-vector leafhopper on host and non-host plants characterized by electrical penetration graphs. Entomologia Experimentali et Applicata, 155, 123-136

Tishechkin, D.Y. (1999) The variability of acoustic signals and some morphological characters in Psammotettix striatus (Homoptera, Cicadellidae) from Russia and adjacent countries. Zoologičenskij žurnal, 78, 1298-1305 (in Russian)

Tishechkin, D.Y. (2000) Vibrational communication in Aphrodinae leafhoppers (Deltocephalinae auct., Homoptera: Cicadellidae) and related groups with notes on classification of higher taxa. Russian Entomological Journal, 9, 1-66

Vacke, J. (1961) Wheat dwarf virus disease. Biologia Plantarum, 3, 228-233.

Virant-Doberlet, M., Čokl, A. and Zorović, M. (2006) Use of substrate vibrations for orientation: from behaviour to physiology. Insect Sounds and Communication: Physiology Behaviour and Ecology (eds. S. Drosopoulos \& M. F. Claridge), Taylor and Francis, Boca Ratoon, pp. 81-97

Virant-Doberlet, M. and Žežlina, I. (2007) Vibrational communication of Metcalfa pruinosa (Hemiptera: Fulgoroidea; Flatidae). Annals of Entomological Society of America, 100, $73-82$

Wan, G.J., Jiang, S.L., Wang, W.J., Li, G.Q., Tao, X.R., Pan, W.D., Sword, G.A. and Chen, F.J. (2015) Rice stripe virus counters reduced fecundity in its vector by modifying insect physiology, primary endosymbionts and feeding behaviour. Scientific Reports, 5, 12527. 
623 Wintraub, P.G. and Beanland, L.A. (2006) Insect vectors of phytoplasmas. Annual Review of $624 \quad$ Entomology, 53, 91-111

625 Zhang, X., Zhou, G.H., Wang, X.F. (2010) Detection of wheat dwarf virus (WDV) in wheat and vector leafhopper (Psammotettix alienus Dahlb.) by real-time PCR. Journal of Virological Methods, 169, 416-419

Table 1 Temporal and spectral parameters of the male calling songs included in the stimulation sequence used to test preferences of Psammotettix alienus females.

\begin{tabular}{lccccc}
\hline \multicolumn{1}{c}{ Male calling song } & $\begin{array}{c}\text { Sequence } \\
\text { duration (s) }\end{array}$ & $\begin{array}{c}\text { Number } \\
\text { of pulse trains }\end{array}$ & $\begin{array}{c}\text { Pulse train } \\
\text { duration (ms) }\end{array}$ & $\begin{array}{c}\text { Pulse train } \\
\text { repetition time (s) }\end{array}$ & $\begin{array}{c}\text { D } \\
\text { freo }\end{array}$ \\
\hline P. alienus, virus-free & 10 & 12 & $76 \pm 5$ & $0.88 \pm 0.34 \mathrm{~s}$ & 586 \\
P. alienus, WDV-b & 19 & 12 & $68 \pm 6$ & $1.7 \pm 1.1 \mathrm{~s}$ & 375 \\
P. confinis 1 & 19 & 41 & $40 \pm 9$ & $0.46 \pm 0.21 \mathrm{~s}$ & 703 \\
P. confinis 2 & 10 & 25 & $40 \pm 5$ & $0.41 \pm 0.16 \mathrm{~s}$ & 773 \\
G. ventralis & 7 & 70 & $62 \pm 21$ & $0.10 \pm 0.03 \mathrm{~s}$. & 280 \\
\hline
\end{tabular}

Means \pm standard deviations are shown while for dominant frequency medians, minimum and maximum measured values (in brackets) are given.

WDV-b: individuals viruliferous for the WDV barley strain. 


\begin{tabular}{llcc}
\hline Male status & Female status & $\boldsymbol{N}$ & $\boldsymbol{N}_{\boldsymbol{v}}$ \\
\hline virus-free & virus-free & 7 & 3 \\
virus-free & WDV-w & 1 & - \\
virus-free & WDV-b & 1 & 1 \\
WDV-w & virus-free & 1 & - \\
WDV-w & WDV-w & 1 & - \\
WDV-w & WDV-b & 2 & 2 \\
WDV-b & virus-free & 1 & 1 \\
WDV-b & WDV-w & 1 & - \\
WDV-b & WDV-b & 3 & - \\
\hline
\end{tabular}

Table 2 Sanitary status of Psammotettix alienus individuals included in observations of mating behaviour.

$N$ : number of pairs included in observations.

$N_{V}$ : subset in which mating behaviour was also recorded on video.

667 WDV-w: individuals viruliferous for the WDV wheat strain.

668 WDV-b: individuals viruliferous for the WDV barley strain.

669 
677 Table 3 Temporal and spectral properties of vibrational signals emitted by Psammotettix alienus.

\begin{tabular}{|c|c|c|c|c|c|c|c|}
\hline & $N$ & $n$ & $\begin{array}{c}\text { Pulse repetition } \\
\text { time }(\mathrm{ms})\end{array}$ & $N$ & $n$ & $\begin{array}{c}\text { Pulse train } \\
\text { duration (s) }\end{array}$ & $\begin{array}{r}\text { Dominant } \\
\text { frequency }(\mathbf{H}\end{array}$ \\
\hline Male calling song - virus free & 9 & 94 & $6 \pm 1$ & 28 & 344 & $0.07 \pm 0.01$ & $492(141-107$ \\
\hline Male calling song - WDV-w & 5 & 51 & $7 \pm 1$ & 7 & 99 & $0.08 \pm 0.01$ & $409(129-603$ \\
\hline Male calling song - WDV-b & 10 & 93 & $7 \pm 1$ & 12 & 134 & $0.08 \pm 0.01$ & $345(129-991$ \\
\hline Male calling song - progeny, virus free & 9 & 92 & $6 \pm 1$ & 9 & 74 & $0.08 \pm 0.01$ & $609(375-91$ \\
\hline Female calling song - virus free & 8 & 75 & $20 \pm 6$ & 18 & 221 & $0.45 \pm 0.06$ & $363(117-914$ \\
\hline Female calling song - WDV-w & 5 & 49 & $20 \pm 4$ & 5 & 52 & $0.46 \pm 0.10$ & $492(492-539$ \\
\hline Female calling song - WDV-b & 10 & 99 & $24 \pm 3$ & 14 & 156 & $0.42 \pm 0.05$ & $387(234-72$ \\
\hline Female calling song - progeny, virus free & 3 & 33 & $15 \pm 5$ & 3 & 140 & $0.48 \pm 0.06$ & $469(375-51$ \\
\hline Courtship signal & 8 & 28 & $300 \pm 32$ & 8 & 28 & $8.09 \pm 1.47$ & $140(108-450$ \\
\hline Masking signal & 7 & 516 & $13 \pm 2$ & 7 & 160 & $4.03 \pm 2,09$ & $574(390 \pm 11$ \\
\hline
\end{tabular}

680

681

682

683

684

685

686

687

688

689

690

691

692

693

694

695

696

697

698

699

Means \pm standard deviations are shown while for dominant frequency medians, minimum and maximum measured values (in brackets) are given.

WDV-w: individuals viruliferous for the WDV wheat strain.

WDV-b: individuals viruliferous for the WDV barley strain.

A - Pulse train repetition time of the viruliferous males was statistically different than in the virus-free males (Student`s t-Test, $P=0.004$ ); B - Pulse train repetition time of the virus-free progeny males was statistically different from the field-collected virus-free males (Student's t-Test, $P=0.004)$.

Table 4 Responsiveness parameters of Psammotettix alienus females to stimulation with conspecific and heterospecific male calling songs,
Male calling song
Calling females (\%)
Female calling song latency (s)
Female calling son

This article is protected by copyright. All rights reserved. 


\begin{tabular}{lccccc}
\hline & Virus-free & WDV-b & Virus-free & WDV-b & Virus-free \\
\hline$P$. alienus, virus-free & 15.4 & 38.5 & $5.23 \pm 3.18$ & $8.68 \pm 4.07$ & $41,3 \pm 30,1$ \\
$P$. alienus, WDV-b & 11.5 & 19.2 & $18.04 \pm 13.72$ & $10.86 \pm 7,62$ & $34,0 \pm 34,6$ \\
P. confinis 1 & 7.7 & 7.7 & $7.8 ; 13.5$ & $14.2 ; 6.8$ & $92 ; 2$ \\
$P$. confinis 2 & 0 & 0 & - & - & - \\
G. ventralis & 0 & 0 & - & - & - \\
\hline
\end{tabular}

700

701

702

703

704

705

Means \pm standard deviations are shown. When $\mathrm{N}<3$, measured values are given.

707

Significantly higher number of females started calling during the presentation of the

conspecific male calling songs (Test of equal or given proportions, $P<0.001$ ).

709

710

711

Fig 1. Nightly calling activity of individual male and female Psammotettix alienus. Virus-free females $(N=2)$; black circle and black diamond; Virus-free males $(N=3)$ : white squares; WDV-W infected male $(\mathrm{N}=1)$ : asterisk; WDV-b infected male $(\mathrm{N}=1)$ : cross.

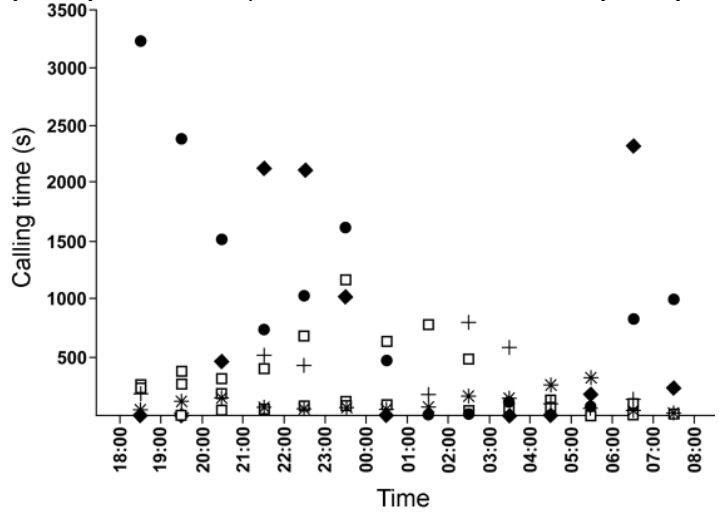

Fig. 2 Male (A) and female (B) calling song of Psammotettix alienus. For each signal, the spectrogram is shown above the corresponding waveform. Insets show expanded individual female pulse trains. A male (M) - female (F) duet shown in (B) was registered during the approach stage.

This article is protected by copyright. All rights reserved. 


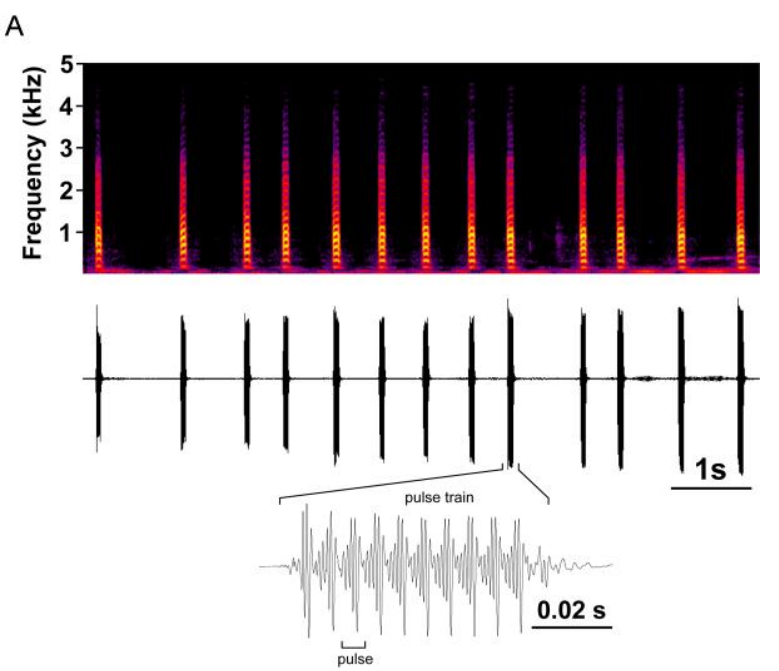

$\mathrm{B}$
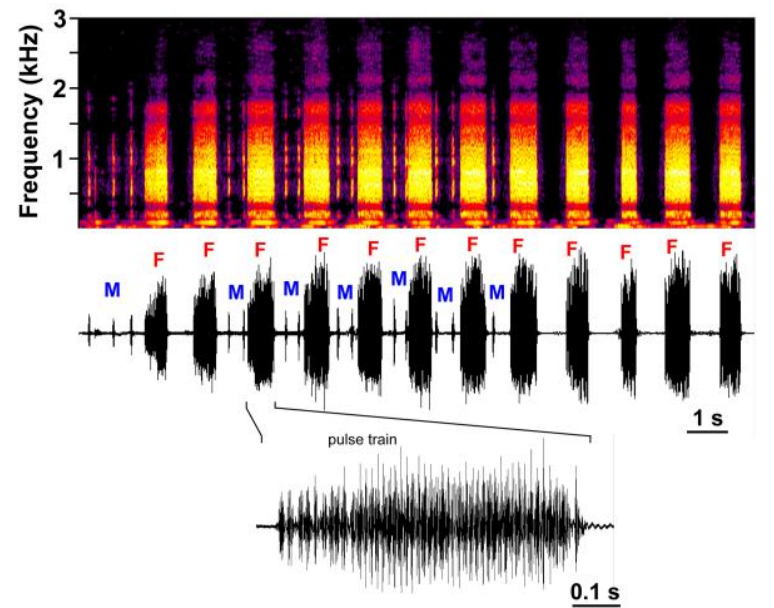

Fig. 3 Coordinated male (M) - female (F) duet in Psammotettix alienus registered during the recognition stage.

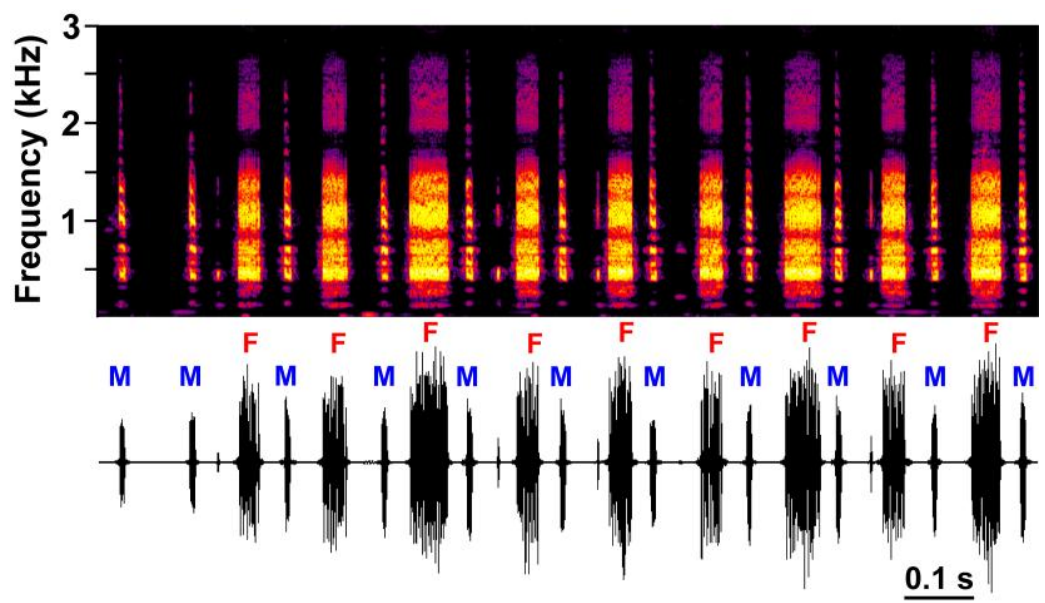

Fig. 4 Representative courtship (a) and pre-copulatory (b) signals emitted by male Psammotettix alienus.

This article is protected by copyright. All rights reserved. 
Inset in (a) shows expanded section of the signal.

A
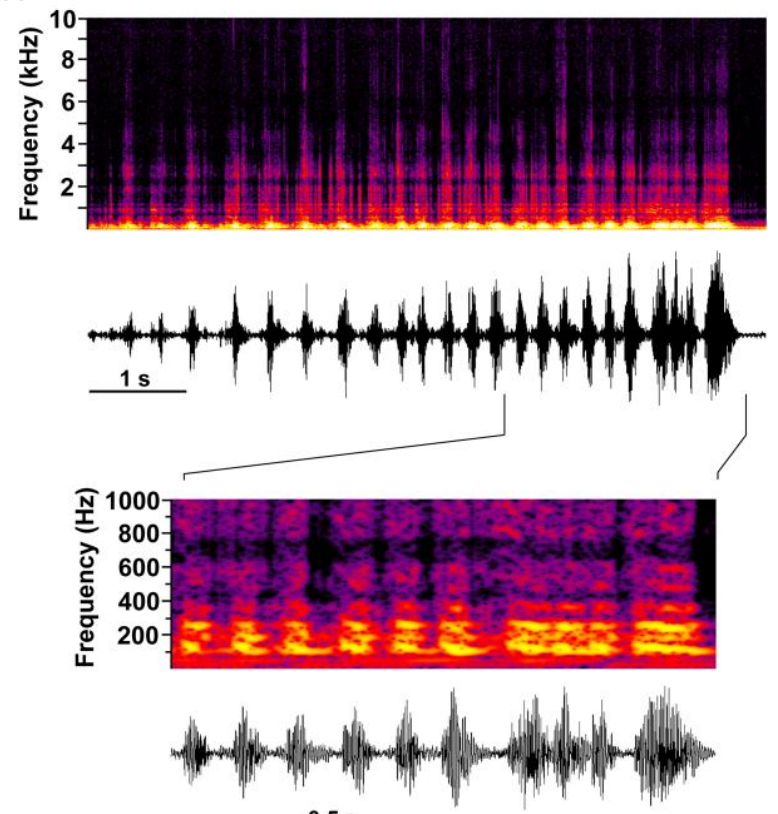

B
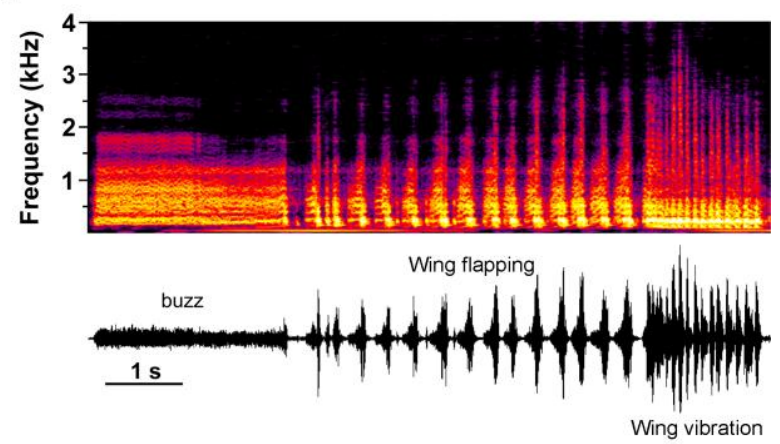

Fig. 5 Putative masking signals (MS) emitted by male Psammotettix alienus. (F) female pulse trains. Inset shows expanded section of the signal.

This article is protected by copyright. All rights reserved. 

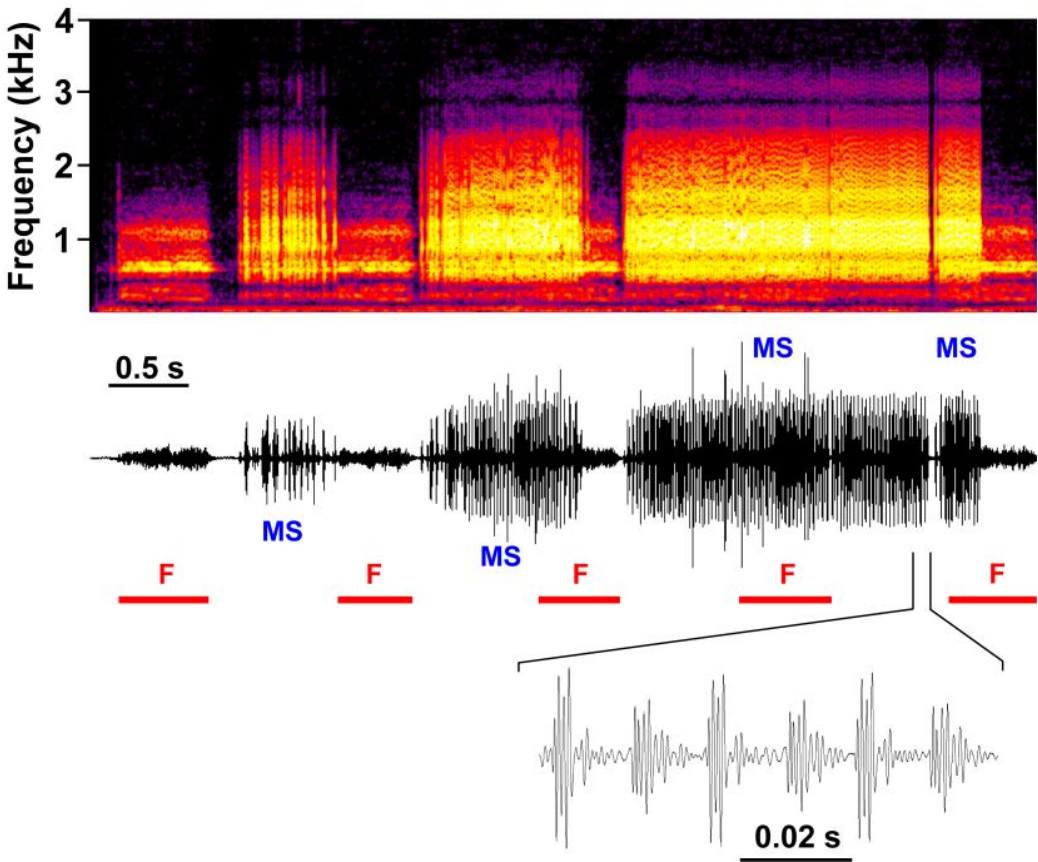

This article is protected by copyright. All rights reserved. 